\title{
FAKTOR-FAKTOR YANG MEMPENGARUHI PEMILIHAN JENIS KONTRASEPSI PADA WANITA USIA SUBUR DI KECAMATAN SEMANU KABUPATEN GUNUNGKIDUL YOGYAKARTA
}

\author{
FACTORS RELATED TO THE SELECTION OF CONTRACEPTION ON \\ REPRODUCTIVE WOMAN IN SEMANU, GUNUNG KIDUL, YOGYAKARTA
}

\author{
Adina Nugrahaeni Wijayanti ${ }^{1}$, Yosi Febrianti ${ }^{1}$, Daru Estiningsih*2 \\ ${ }^{1}$ Prodi Farmasi, Fakultas MIPA Universitas Islam Indonesia. \\ ${ }^{2}$ Prodi Farmasi, Fakultas Ilmu-Ilmu Kesehatan, Universitas Alma Ata \\ *Penulis Korespodensi, email: daru.estiningsih@gmail.com
}

\begin{abstract}
ABSTRAK
Ledakan penduduk merupakan salah satu masalah yang ada di negara berkembang seperti Indonesia yang merupakan negara dengan jumlah Wanita Usia Subur (WUS) terbesar di Asia Tenggara. Untuk mengatasi permasalahan ini, pemerintah menerapkan program Keluarga Berencana $(\mathrm{KB})$ untuk mengontrol laju pertumbuhan masyarakat dengan menggunakan alat kontrasepsi yang pemilihannya dipengaruhi oleh beberapa faktor sehingga tercipta sumber daya yang berkualitas. Tujuan dari penelitian ini adalah untuk mengetahui faktor-faktor yang mempengaruhi pemilihan metode kontrasepsi di Kecamatan Semanu Kabupaten Gunungkidul Yogyakarta. Penelitian ini merupakan penelitian analitik kuantitatif dengan rancangan penelitian cross sectional dengan instrumen penelitian berupa kuesioner yang telah divalidasi menggunakan content validity. Waktu pengambilan sampel dilaksanakan pada bulan Juni 2016. Sampel diambil dengan menggunakan metode accidental sampling dan besarnya sampel dihitung dengan rumus slovin. Analisis data menggunakan analisis bivariat dengan uji chisquare. Hasil penelitian menunjukkan bahwa yang mempengaruhi pemilihan jenis kontrasepsi di Kecamatan Semanu adalah faktor pekerjaan $(\mathrm{p}=0,033)$ dan pengalaman efek samping $(\mathrm{p}=0,000)$.
\end{abstract}

Kata kunci: kontrasepsi, faktor, pemilihan kontrasepsi

\begin{abstract}
Human overpopulation is one of serious problems faced by many developing countries like Indonesia. Indonesia moreover is the biggest country for Woman of Reproduction Age in South East Asia. To solve it, the goverment is currently developing family planning program uses contraception which is choosed by some factors in order to improve quality of human resources. This research aims to find out the factors which are influence contraception acceptors to choose contraception methode in Semanu, Gunungkidul, Yogyakarta. This research is categorized as analitic quantitative with cross sectional research design. The instrument of this research is questionnaire which has been validated using content validity. For the purpose of sample taking, this research is conducted in June, 2016. Sample is taken by using accidental sampling method and then calculated using slovin formula. To analyze the data, the researcher uses bivariat analysis, chi-square test. The result of this study indicate that occupation
\end{abstract}


factors $(p=0.033)$ and side efect $(p=0.000)$ influence the choice of contraception methode in Semanu.

Keywords: contraception, factors, contraception selection

\section{PENDAHULUAN}

Population Data Sheet 2013 menyatakan bahwa Indonesia menduduki peringkat ke 5 untuk negara dengan jumlah penduduk terbanyak, yaitu 249 juta. Indonesia dengan luas wilayah terbesar di antara negara ASEAN menjadi negara dengan penduduk terbanyak, jauh di atas 9 negara anggota lain. Angka Fertilitas atau Total Fertility Rate (TFR) sebesar 2,6. Hasil ini menunjukkan bahwa Indonesia masih berada di atas ratarata TFR negara ASEAN, yaitu sebesar 2,4 (Kemenkes, 2011). Indonesia merupakan negara degan jumlah Pasangan Usia Subur (PUS) terbesar di Asia Tenggara, kemudian diikuti Vietnam dan Filipina (Mujiati, et al., 2013). Berdasarkan data Badan Pusat Statistik (BPS, 2015), Daerah Istimewa Yogyakarta memiliki luas area $3.185,80 \mathrm{~km}^{2}$ dan Kabupaten Gunungkidul menempati luas sebesar 1.485,36 $\mathrm{km}^{2}$ dengan kepadatan $1.939 \mathrm{jiwa} / \mathrm{km}^{2}$. Seiring dengan meningkatnya jumlah penduduk Indonesia serta tingginya angka kematian ibu dan kebutuhan akan kesehatan reproduksi, digunakan program Keluarga Berencana $(\mathrm{KB})$ sebagai salah satu cara untuk menekan pertumbuhan penduduk serta meningkatkan kesehatan ibu dan anak. Pengaturan kehamilan dalam program KB ini dilakukan dengan menggunakan alat kontrasepsi (Kemenkes, 2014).

Kontrasepsi adalah cara untuk mencegah kehamilan pada pasangan usia subur (Sinsin, 2008). Data peserta KB baru di Indonesia tahun 2013 menunjukkan metode kontrasepsi yang paling banyak digunakan PUS adalah kontrasepsi suntik, yaitu sebanyak 4.128.115 PUS, diikuti dengan kontrasepsi pil sebanyak 2.261.480 PUS, kontrasepsi implan sebanyak 784.215 PUS dan IUD sebanyak 658.632 PUS (Kemenkes, 2014). Bulan Februari 2015, mayoritas peserta KB baru di Indonesia didominasi oleh penggunaan Non Metode Kontrasepsi Jangka Panjang (Non MKJP), yaitu sebesar $81,83 \%$ dari seluruh peserta KB baru dan 18,17\% peserta menggunakan Metode Kontrasepsi Jangka Panjang dan faktor-faktor yang mempengaruhi penggunaan kontrasepsi di wilayah Jawa adalah variabel umur PUS, jumlah anak masih hidup lama menikah dan tingkat pendidikan (Nasution et al., 2011).

Kecamatan Semanu merupakan bagian dari wilayah Kabupaten Gunungkidul, Yogyakarta. Sebagai daerah rural Kecamatan Semanu Kabupaten Gunungkidul memiliki potensi perekonomian dari pertanian,perikanan, peternakan, hutan, flora dan fauna, industri, tambang dan potensi pariwisata. Jumlah akseptor KB aktif di Kecamatan Semanu menurut jenis kontrasepsi yang sedang digunakan yaitu IUD sebanyak 956 PUS, pil sebanyak 1454 PUS, suntik sebanyak 5461 PUS, dan implan sebanyak 732 PUS (BPS, 2015). Hal yang mendasari dipilihnya Kecamatan Semanu sebagai tempat penelitian adalah belum ada penelitian terkait faktor-faktor yang mempengaruhi pemilihan metode kontrasepsi. Berdasarkan latar belakang di atas, tujuan penelitian ini adalah mengetahui faktor-faktor apa saja yang berhubungan dengan wanita usia subur (WUS) dalam memilih jenis kontrasepsi. 


\section{METODE PENELITIAN}

Penelitian ini merupakan penelitian analitik dengan rancangan penelitian cross sectional. Data yang diperoleh dari data primer dan data sekunder dengan instrumen penelitian berupa kuisioner.

\section{Bahan dan Alat}

Instrumen penelitian berupa kuesioner yang berisi identitas responden, pertanyaan mengenai penilaian informasi, pengetahuan yang mengacu pada tesis yang ditulis oleh Purba (2009). Jenis kuesioner bersifat tertutup dengan pertanyaan dan pilihan jawaban benar atau salah. Kuesioner terdiri dari tiga komponen, yaitu identitas responden yang terdiri dari 13 pertanyaan, penilaian informasi yang terdiri dari 11 pertanyaan dan penilaian pengetahuan yang terdiri dari 20 pertanyaan. Penilaian pengetahuan dibagi menjadi 4 bagian yaitu pengetahuan kontrasepsi secara umum, pengetahuan cara pakai, pengetahuan indikasi-kontraindikasi dan pengetahuan efek samping. Penilaian kelayakan instrumen dilakukan dengan uji validitas dan uji reliabilitas.

\section{Jalannya Penelitian}

Penelitian ini diaksanakan di Kecamatan Semanu Kabupaten Gunungkidul selama 1 bulan, yaitu bulan Mei hingga bulan Juni 2016. Populasi dalam penelitian ini adalah akseptor kontrasepsi pil, suntik, implan dan IUD di Kecamatan Semanu. Subjek penelitian ini adalah wanita usia subur (WUS) yang memenuhi kriteria inklusi, yaitu usia 15-49 tahun, terdaftar sebagai peserta KB aktif di Kecamatan Semanu dan bersedia menjadi responden.Sampel diambil menggunakan metode accidental sampling.

\section{Analisis Data}

Uji chi-square digunakan untuk mengetahui pengaruh faktor usia, pendidikan, pekerjaan, pendapatan, dukungan suami, sumber informasi, pengalaman efek samping dan tingkat pengetahuan terhadap pemilihan kontrasepsi. Jika nilai Sig. (Signifikansi) atau nilai probabilitas $<0,05$, artinya ada hubungan signifikan antara faktor dengan pemilihan jenis kontrasepsi. Jika nilai Sig. (Signifikansi) atau nilai probabilitas $>0,05$, artinya tidak ada hubungan signifikan antara faktor dengan pemilihan jenis kontrasepsi.

\section{HASIL DAN PEMBAHASAN}

Penelitian ini diaksanakan di Kecamatan Semanu Kabupaten Gunungkidul selama 1 bulan, yaitu bulan Mei hingga bulan Juni 2016. Populasi dalam penelitian ini adalah akseptor kontrasepsi pil, suntik, implan dan IUD di Kecamatan Semanu. Subjek penelitian ini adalah wanita usia subur (WUS) yang memenuhi kriteria inklusi, yaitu usia 15-49 tahun, terdaftar sebagai peserta KB aktif di Kecamatan Semanu dan bersedia menjadi responden.Sampel diambil menggunakan metode accidental sampling. Jumlah sampel didapat dari perhitungan rumus slovin, digunakan rumus slovin karena populasi nya diketahui, dari hasil perhitungan diperoleh jumlah minimal sampel adalah 99, selama periode penelitian diperoleh sampel sejumlah 109 .

Jenis kontrasepsi dalam penelitian ini meliputi penggunaan pil, suntik, implan dan IUD yang digunakan di Kecamatan Semanu. Kontrasepsi suntik merupakan 
kontrasepsi yang paling banyak digunakan di antara kontrasepsi yang lain. Gambar 1 memperlihatkan persentase penggunaan kontrasepsi pil, suntik, implant, dan IUD di Kecamatan Semanu.



Gambar 1. Persentase penggunaan kontrasepsi kecamatan semanu

Kuisoner diberikan kepada 109 pasangan usia subur yang terpilih menjadi sampel penelitian. Berdasarkan kuesioner yang diisi oleh responden, mayoritas responden telah menggunakan kontrasepsi selama 5 tahun dan mereka mendapatkan kontrasepsi untuk pertama kalinya melalui bidan. Karakteristik responden dikategorikan menjadi usia, pendidikan, pekerjaan, dan pendapatan, seperti tersaji pada Tabel I.

Usia merupakan salah satu penentu dalam memilih jenis kontrasepsi, karena dengan melihat usia dapat dilihat fase-fase tertentu terkait dengan tingkat reproduksi seseorang (Rizali et al., 2013). Menurut variabel usia PUS hasil analisis BKKBN, dapat ditentukan fase-fase penggunaan alat kontrasepsi yang ideal. Usia kurang dari 20 tahun merupakan fase menunda kehamilan pada wanita yang menikah di usia kurang dari 20 tahun, usia 20-35 tahun merupakan fase dimana PUS ingin menjarangkan kehamilan dengan mengatur jarak kehamilan dan usia 35 tahun keatas adalah fase mengakhiri kehamilan (Nasution et al., 2011). Hasil penelitian Kahraman et al. (2012), 62,7\% wanita pengguna kontrasepsi adalah di atas usia 30 tahun dan pada tingkatan usia kurang dari 20 tahun penggunaan kontrasepsi tergolong rendah.

Selain usia, pendidikan, pekerjaan dan pendapatan, faktor lain yang diteliti adalah sumber informasi, pengalaman efek samping, dukungan suami, dan tingkat pengetahuan. Sumber informasi adalah informasi yang diperoleh subjek penelitian dari media cetak, media elektronik dan tenaga kesehatan Diperoleh data bahwa 94 responden mendapat informasi dari tenaga kesehatan, baik dari dokter, bidan atau apoteker. Responden yang mendapat informasi dari internet sebanyak 1 responden, media sosial sebanyak 3 responden, keluarga sebanyak 9 responden dan yang mendapat informasi dari teman sebanyak 2 responden. Menurut penelitian Osmani (2015), pengaruh media masa dapat meningkatkan pengetahuan terkait metode kontrasepsi dan dapat meningkatkan kesadaran untuk menggunakan kontrasepsi. 
Tabel I. Karakteristik respoden akseptor KB Kec. Semanu 2016

\begin{tabular}{|c|c|c|}
\hline Karakteristik & Jumlah responden (n) & $\%$ \\
\hline \multicolumn{3}{|l|}{ Usia } \\
\hline \multirow{3}{*}{$\begin{array}{l}15-20 \\
21-35 \\
36-49\end{array}$} & 1 & 0,92 \\
\hline & 57 & 52,29 \\
\hline & 51 & 46,789 \\
\hline \multicolumn{3}{|l|}{ Pendidikan } \\
\hline SLTP & 49 & 44,95 \\
\hline SD & 32 & 29,36 \\
\hline SLTA & 28 & 25,69 \\
\hline Sarjana (S1) & 0 & 0 \\
\hline $\mathrm{S} 2 / \mathrm{S} 3$ & 0 & 0 \\
\hline Tidak sekolah & 0 & 0 \\
\hline \multicolumn{3}{|l|}{ Pekerjaan } \\
\hline Ibu rumah tangga & 85 & 77,98 \\
\hline Petani & 13 & 11,93 \\
\hline Wiraswasta & 9 & 8,26 \\
\hline Buruh & 2 & 1,83 \\
\hline Pegawai swasta & 0 & 0 \\
\hline \multirow{2}{*}{$\begin{array}{l}\text { Pegawai negeri } \\
\text { Mahasiswa }\end{array}$} & 0 & 0 \\
\hline & 0 & 0 \\
\hline \multicolumn{3}{|l|}{ Pendapatan } \\
\hline$<1$ juta & 93 & 85,32 \\
\hline $1-3$ juta & 14 & 12,84 \\
\hline $3-5$ juta & 2 & 1,84 \\
\hline$>5$ juta & 0 & 0 \\
\hline Total & 109 & 100 \\
\hline
\end{tabular}

Terdapat beberapa responden yang melakukan pergantian dari kontrasepsi satu ke kontrasepsi yang lain karena beberapa alasan, seperti terlihat pada Tabel II. Di antaranya karena mengalami efek samping, terjadi kegagalan atau terjadi kehamilan, menyesuaikan pendapatan keluarga dan mengikuti saran dari orang lain. Efek samping kontrasepsi adalah respon subjektif yang dirasakan oleh responden setelah penggunaan kontrasepsi pada penelitian ini diperoleh bahwa 36 responden memiliki pengalaman efek samping.

Dukungan suami adalah dukungan yang didapatkan subjek penelitian dari suami untuk memilih dan menggunakan kontrasepsi. Dukungan suami dalam menggunakan kontrasepsi merupakan hal yang dibutuhkan untuk keberhasilan pemakaian kontrasepsi. Bentuk dukungan suami dapat berupa mengantar saat pemasangan alat kontrasepsi atau menemani saat konseling dengan bidan atau dokter. Dukungan suami dalam pemakaian kontrasepsi biasanya didapatkan karena suami ingin memberi jarak kelahiran anak atau karena kesulitan ekonomi yang dialami dalam memenuhi kebutuhan. Terkait dengan pemilihan jenis kontrasepsi, suami juga berperan dalam menentukan jenis kontrasepsi 
yang memberi kenyamanan dan tidak mengganggu hubungan seksual (Rizali et al., 2013). Responden penelitian ini seluruhnya mendapat dukungan dari suami untuk menggunakan kontrasepsi.

Tabel II. Riwayat Penggantian Kontrasepsi oleh Responden di Kecamatan Semanu

\begin{tabular}{|c|c|c|c|c|c|c|c|c|c|}
\hline No & \multicolumn{2}{|c|}{ Penggunaan kontrasepsi } & Jumlah (n) & $\%$ & \multicolumn{5}{|c|}{ Alasan Penggantian } \\
\hline & Sebelumnya & Sekarang & & & 1 & 2 & 3 & 4 & 5 \\
\hline 1. & IUD & Pil & 2 & 4,87 & 1 & - & - & - & 1 \\
\hline 2. & IUD & Suntik & 4 & 9,76 & 4 & - & - & - & - \\
\hline 3. & IUD & Implan & 2 & 4,87 & 2 & - & - & - & - \\
\hline 4. & Suntik & IUD & 6 & 14,63 & 5 & - & 1 & - & - \\
\hline 5. & Suntik & Pil & 12 & 29,26 & 10 & 1 & 1 & - & - \\
\hline 6. & Suntik & Implan & 4 & 9,76 & 3 & - & - & 1 & - \\
\hline 7. & Pil & IUD & 4 & 9,76 & 4 & - & - & - & - \\
\hline 8. & Pil & Suntik & 9 & 21,95 & 7 & 1 & 1 & - & - \\
\hline Tot & & & 41 & 100 & 36 & 2 & 3 & 1 & 1 \\
\hline
\end{tabular}

Keterangan :

1. Mengalami efek samping pada penggunaan kontrasepsi sebelumnya.

2. Menyesuaikan dengan pendapatan keluarga.

3. Mengalami kegagalan, karena terjadi kehamilan.

4. Mengikuti saran dari orang sekitar.

5. Lainnya.

Tingkat pengetahuan adalah kemampuan akseptor dalam menjawab kuisioner dengan benar pengetahuan memiliki kontribusi besar dalam mengubah perilaku manusia dan berbuat sesuatu. Berdasarkan hasil penelitian sebelumnya, didapatkan bahwa semakin tinggi tingkat pengetahuan seseorang tentang alat kontrasepsi maka akan memilih kontrasepsi suntik (Rizali et al., 2013). Dalam hal ini, pemilihan kontrasepsi suntik bukan karena responden memiliki pengetahuan tinggi, melainkan karena mengikuti jenis kontrasepsi yang digunakan oleh saudara atau teman terdekatnya.

Faktor-faktor yang diteliti dalam penelitian ini adalah faktor usia, pendidikan, pekerjaan, pendapatan, dukungan suami, sumber informasi, pengalaman efek samping dan tingkat pengetahuan. Faktor-faktor tersebut diteliti pada 109 sampel WUS di Kecamatan Semanu yang memenuhi kriteria inklusi. Untuk mengetahui pengaruh faktor usia, pendidikan, pekerjaan, pendapatan, dukungan suami, sumber informasi, pengalaman efek samping dan tingkat pengetahuan terhadap pemilihan kontrasepsi maka digunakan Uji chi-square.

Faktor pekerjaan memiliki hasil $\mathrm{p}=0,033(\mathrm{p}<0,05)$ yang artinya pekerjaan berhubungan dengan pemilihan jenis kontrasepsi. Pekerjaan sebagian besar responden adalah ibu rumah tangga (77,98\%), selain itu ada yang menjadi petani $(11,93 \%)$, wiraswasta $(8,26 \%)$ dan buruh $(1,83 \%)$. Jika dilihat dari pekerjaan, responden memilih jenis kontrasepsi suntik karena mereka tidak memiliki kesibukan yang dapat 
Tabel III. Nilai P Value Tiap Faktor yang Berhubungan dengan Pemilihan Kontrasepsi

\begin{tabular}{|c|c|c|c|c|c|}
\hline \multirow[t]{2}{*}{ Kategori Responden } & \multicolumn{4}{|c|}{ Pemilihan Kontrasepsi } & \multirow[t]{2}{*}{ p value } \\
\hline & Pil & Suntik & Implan & IUD & \\
\hline \multicolumn{6}{|l|}{ Usia } \\
\hline $15-20$ & 0 & 0 & 0 & 1 & \multirow{3}{*}{0,270} \\
\hline $21-35$ & 12 & 28 & 4 & 13 & \\
\hline $36-49$ & 6 & 34 & 3 & 8 & \\
\hline \multicolumn{6}{|l|}{ Pendidikan } \\
\hline Tidak sekolah & 0 & 0 & 0 & 0 & \multirow{6}{*}{0,091} \\
\hline SD & 4 & 21 & 1 & 6 & \\
\hline SLTP & 12 & 28 & 3 & 6 & \\
\hline SLTA & 2 & 13 & 3 & 10 & \\
\hline Sarjana (S1) & 0 & 0 & 0 & 0 & \\
\hline $\mathrm{S} 2 / \mathrm{S} 3$ & 0 & 0 & 0 & 0 & \\
\hline \multicolumn{6}{|l|}{ Pekerjaan } \\
\hline Wiraswasta & 0 & 8 & 0 & 1 & \multirow{7}{*}{0,033} \\
\hline Pegawai negeri & 0 & 0 & 0 & 0 & \\
\hline Pegawai swasta/karyawan & 0 & 0 & 0 & 0 & \\
\hline Petani & 2 & 10 & 0 & 1 & \\
\hline Buruh & 2 & 0 & 0 & 0 & \\
\hline Mahasiswa & 0 & 0 & 0 & 0 & \\
\hline Ibu rumah tangga & 14 & 44 & 7 & 20 & \\
\hline \multicolumn{6}{|l|}{ Pendapatan } \\
\hline$<1$ juta & 18 & 52 & 6 & 17 & \multirow{4}{*}{0,407} \\
\hline $1-3$ juta & 0 & 8 & 1 & 5 & \\
\hline 3-5 juta & 0 & 2 & 0 & 0 & \\
\hline$>5$ juta & 0 & 0 & 0 & 0 & \\
\hline \multicolumn{6}{|l|}{ Dukungan suami } \\
\hline $\mathrm{Ya}$ & 18 & 62 & 7 & 22 & \multirow[t]{2}{*}{-} \\
\hline Tidak & 0 & 0 & 0 & 0 & \\
\hline \multicolumn{6}{|l|}{ Sumber informasi } \\
\hline Internet & 0 & 0 & 0 & 1 & \multirow{8}{*}{0,059} \\
\hline Media sosial & 1 & 2 & 0 & 0 & \\
\hline TV & 0 & 0 & 0 & 0 & \\
\hline Radio & 0 & 0 & 0 & 0 & \\
\hline Media cetak & 0 & 0 & 0 & 0 & \\
\hline Tenaga kesehatan & 12 & 57 & 7 & 18 & \\
\hline Keluarga & 3 & 3 & 0 & 3 & \\
\hline Teman & 2 & 0 & 0 & 0 & \\
\hline \multicolumn{6}{|l|}{ Efek samping } \\
\hline Ya & 14 & 11 & 4 & 7 & \multirow{2}{*}{0,000} \\
\hline Tidak & 4 & 51 & 3 & 15 & \\
\hline \multicolumn{6}{|l|}{ Tingkat pengetahuan } \\
\hline Tinggi & 5 & 32 & 2 & 10 & \multirow{3}{*}{0,503} \\
\hline Sedang & 11 & 27 & 5 & 11 & \\
\hline Rendah & 2 & 3 & 0 & 1 & \\
\hline
\end{tabular}


menyebabkan mereka lupa atau tidak punya waktu untuk melakukan penyuntikan setiap sebulan sekali maupun tiga bulan sekali. Hasil penelitian dari Islam, I (2013), bahwa perempuan dengan keterampilan yang tinggi akan cenderung memilih kontrasepsi modern dengan dibanding kontrasepsi tradisional.

Faktor pengalaman efek samping memiliki hasil $\mathrm{p}=0,000(\mathrm{p}<0,05)$, yang artinya ada hubungan antara pengalaman efek samping dengan pemilihan jenis kontrasepsi. Responden yang pernah mengalami efek samping pada penggunaan jenis kontrasepsi sebelumnya, akan beralih pada jenis kontrasepsi yang dilihat lebih aman dan nyaman digunakan. Hasil penelitian ini, ada 36 responden yang memiliki pengalaman efek samping dan 73 responden tidak memiliki pengalaman efek samping. Sejalan dengan penelitian yang dilakukan oleh Rizali, bahwa pengalaman efek samping berhubungan dengan pemilihan jenis kontrasepsi (Rizal., M. dkk, 2013).

\section{KESIMPULAN}

Faktor yang berhubungan dengan pemilihan jenis kontrasepsi pada PUS di Kecamatan Semanu menurut hasil penelitian ini adalah pekerjaan dan pengalaman efek samping.

\section{DAFTAR PUSTAKA}

Badan Pusat Statistik, 2015, Kecamatan Semanu dalam Angka 2015, KSK Kecamatan Semanu.

Islam, 2013, Determinants of Contraceptive Method Choice in Bangladesh: Male Perspectives, South East Asia Journal Of Public Health 3(1): 53.

Kahraman, Korhan., Ozmen, Batuhan., 2012, Factors Influencing the Contraceptive Methode Choice: a University Hospital Experience, Turki: J Turkish-German Gynecol Assoc 13: 104.

Kementrian Kesehatan Republik Indonesia, 2011, Kepadatan Penduduk menurut Kabupaten atau Kota di D.I. Yogyakarta Tahun 2011-2015, http://yogyakarta.bps.go.id/linkTabelStatis/view/id/10, diakses 29 April 2016

Kementrian Kesehatan Republik Indonesia, 2014, Situasi dan Analisis Keluarga Berencana, Jakarta.

Mujiati, Budijanti, Khairani, 2013, Situasi Keluarga Berencana di Indonesia, Buletin Jendela Data dan Informasi Kesehatan, Kementrian Kesehatan RI, Jakarta 2(2).

Nasution, Sri, Lilestina., 2011, Faktor-Faktor yang Mempengaruhi penggunaan MKJP di Enam Wilayah Indonesia, Pusat Penelitian dan Pengembangan KB dan Keluarga Sejahtera $B K K B N$, Jakarta.

Osmani A. K., 2015., Factors Influencing Contraceptive Use Among Women in Afghanistan: Secondary Analysis of Afghanistan Health Survey 2012, Jepang: Nagoya Journal Medicine, 77: p. 554. 
Purba, J. T, 2009, Faktor-Faktor yang Mempengaruhi Pemakaian Alat Kontrasepsi pada Istri PUS di Kec. Rambah Kab. Rokan Hulu Tahun 2008, Tesis, Medan: Sekolah Pascasarjana Universitas Sumatera Utara

Rizali, Muhammad., Ikhsan, Muhammad., Salmah, Ummu., 2013, Faktor yang Berhubungan dengan Pemilihan Metode Kontrasepsi Suntik di Kelurahan Mattoangin Kecamatan Mariso Kota Makassar Tahun 2013, Makassar: UNHAS.

Sinsin, 2008, Seri Kesehatan Ibu dan Anak Masa Kehamilan dan Persalinan, Jakarta: PT Elex Media Komputindo. 